\title{
Central Asian wild tulip conservation requires a regional approach, especially in the face of climate change
}

\author{
Brett Wilson $^{1}$ (D) Aibek Dolotbakov ${ }^{2} \cdot$ Benjamin J. Burgess $^{3}$ (ID $\cdot$ Colin Clubbe $^{4}$ (D) \\ Georgy Lazkov² $\cdot$ Kaiyrkul Shalpykov² ${ }^{2}$. Myskalai Ganybaeva² \\ Ormon Sultangaziev ${ }^{5}$. Samuel F. Brockington ${ }^{1}$ (D)
}

Received: 16 November 2020 / Revised: 2 March 2021 / Accepted: 9 March 2021 /

Published online: 27 March 2021

(C) The Author(s) 2021

\begin{abstract}
Tulips (Tulipa spp.) are one of the most widely appreciated plants worldwide, nevertheless species taxonomy and biogeography are often poorly understood. Most wild tulips inhabit the mountains of Central Asia, a recognised biodiversity hotspot, and a centre of tulip diversity. Despite the presence of several country-level endemic Tulipa species, most taxa span the borders of several nations. With no globally Red Listed tulip taxa from this region national level conservation assessments are an important resource. Nonetheless, threats posed to tulips are still inadequately understood, especially climate change, and given the trans-national nature of most species, distributional information is restricted and often misleading. Here we collate 330 species records from the Global Biodiversity Information Facility with 85 newly collected records, to undertake species distribution modelling (MaxEnt) for ten native Central Asian species. This work showed that regional level models provide a much more comprehensive understanding of species' extinction risks, proportions of habitat in different countries, and limitations in protected area coverage. Furthermore, our climate modelling, the first of its kind for tulips, suggests that climate change will have a significant negative impact on the range size of all species; including those that are currently widespread. We therefore add climate change to the list of threats affecting tulip populations in Central Asia, which already includes livestock overgrazing, urbanisation, wild collection, and mining. Overall, our work shows that although national information is important, a regional approach is crucial not just for tulip conservation efforts, but likely for Central Asian plant conservation in general.
\end{abstract}

Keywords Tulipa $\cdot$ Wild tulips $\cdot$ Climate change $\cdot$ Species distribution modelling · MaxEnt · Central Asia

Communicated by Daniel Sanchez Mata.

Brett Wilson

bdw35@cam.ac.uk

Samuel F. Brockington

sb771@cam.ac.uk

Extended author information available on the last page of the article 


\section{Introduction}

Conservation, including conservation assessments such as the global IUCN Red List (IUCN 2020), are underpinned by an array of data. Primarily, they rely on knowledge of a species' distribution and threats to its survival (IUCN 2012). For many species, global IUCN Red Listing has not been undertaken, and this is often due to a lack of information to support these reports (Rodrigues et al. 2006). Local experts can provide a valuable insight into threats to species (Keppel et al. 2015), but commonly only country-level efforts have been undertaken to assess the status of flora, and many National Red Lists are therefore more comprehensive than global ones (Tojibaev and Beshko 2015). This is exacerbated by plants being globally and nationally less commonly assessed than animals (Nic Lughadha et al. 2020), in part due to plant-blindness (Balding and Williams 2016), whilst crucially, many are known to be declining towards extinction and require urgent conservation action (Nic Lughadha et al. 2020). Therefore, there is a need for more information to support plant conservation assessments, especially across the full geographic range of a species. Species distribution modelling presents a method through which to improve understanding of the suitable habitat area of a species (Phillips et al. 2017), developing knowledge of its extinction risk, and promoting population monitoring, management, and related policy, especially across multiple countries (Pearson et al. 2014; Wilson et al. 2019).

Tulips are a group of perennial geophytic monocots (Everett 2013). They are widely recognised for their horticultural varieties which support a billion Euro industry (Christenhusz et al. 2013), but also for their wild species which form a genus that is estimated to comprise between 76 and 90 species (Everett 2013). This array of wild taxa has historically underpinned the large horticultural trade, something that has significantly complicated the taxonomy of this clade (Christenhusz et al. 2013). Wild species remain a significant genetic resource for horticultural breeders, have considerable cultural value, and play an important role in ecosystems, especially for pollinators and insects (Kashin et al. 2016; $\mathrm{Su}$ et al. 2020). Wild tulips grow in the temperate regions of the northern hemisphere. Their distribution covers much of Eurasia, extending from western China across to western Europe, whilst a single species occurs on the Mediterranean coast of Africa. Nonetheless most species distributions centre around Central Asia (Botschantzeva 1982), and specifically the Mountains of Central Asia biodiversity hotspot (Critical Ecosystem Partnership Fund 2016).

Currently, there are only five tulip species published on the global IUCN Red List although none of these are native to the Central Asian centre of diversity (IUCN 2020). For Central Asian tulips an assortment of national level assessments have been published (SAEPF et al. 2006; Khassanov and Prastov 2009; Baitulin 2014; Tojibaev and Beshko 2015; Nowak et al. 2020), but these focus on country-wide distributions, not accounting for the fact that many species' distributions cross national borders. Poor representation is a common problem for Central Asian species, with data often lacking (Yesson et al. 2007; Paton et al. 2020), and international evaluation rare due to geopolitical tensions between neighbouring countries (Nowak et al. 2020). Regardless, national conservation assessments undertaken in this region indicate that a range of tulip species are threatened (SAEPF et al. 2006; Khassanov and Prastov 2009; Baitulin 2014; Tojibaev and Beshko 2015; Nowak et al. 2020). Threats previously recorded for these species include wild collection and trade, livestock overgrazing, and climate change (Nowak et al. 2020), although there remains limited literature and research focused on understanding their impacts. Nonetheless research suggests that the life history, ecology, 
and cultural value of tulips makes them exceptionally vulnerable to disturbance and consequently to extinction (Tojibaev and Beshko 2015; Nowak et al. 2020).

Most tulips grow in the lower and middle elevations of mountain belts (Botschantzeva 1982). These alpine regions are thought to be extremely sensitive to climate change (Rangwala and Miller 2012) and therefore tulips may be especially vulnerable to this increasing threat (Nowak et al. 2020). Nonetheless the lower semi-desert and steppe areas of Central Asia, where fewer tulip species grow, are also reportedly fragile to a changing climate with many areas predicted to becoming increasingly arid in future years (Lioubimtseva and Henebry 2009; Chen et al. 2019). The impacts of climate change in these areas could be exacerbated by tulips' geophytic growth habit, relying on bulb-driven rapid spring growth to survive summer drought conditions common in the temperate latitudes where these species grow (Botschantzeva 1982). However, tulip bulbs also rely on a cold winter period as a trigger for initial growth, a process known as vernalisation. Furthermore, tulips require dry and freely draining soil conditions, with dampness often leading to rot and disease (Wilford 2013). Thus, tulip distributions are tightly linked to seasonal triggers, and both temperature and rainfall patterns, meaning changes in these may lead to declines in population numbers and even local extinctions. Moreover, climate change may cause shifts in suitable habitat and therefore there may be an increasing need for species to rapidly adapt or relocate to survive.

Initial flowering of tulips will not occur until there is a large energy store in the bulb, which can take several growing seasons. In addition, if damage occurs to the bulbs or leaves during the short growing season this can greatly weaken the plant, limit growth and reproduction, and sometimes even lead to death (Wilford 2013). Tulips' relatively long reproductive cycle and vulnerability to damage means that colonisation and repopulation of areas is slow, exacerbated by their limited ability to disperse pollen and seeds (Kashin et al. 2016). Given this and the widespread nature of livestock grazing across the grasslands, pasturelands, shrublands, steppes, and semi-deserts in which this plant commonly grows and the opportunistic collection of flowers by communities, tulips may be at increased risk from disturbance and may be unable to migrate to compensate for climate change (SAEPF et al. 2006; Tojibaev and Beshko 2015; Nowak et al. 2020). Additionally, many species are thought to have small, restricted distributions, especially many described endemics that are often only known from a specific hillside or gorge (Millaku and Elezaj 2015; de Groot and Tojibaev 2017), a trait widely associated with a heightened risk of extinction (Pearson et al. 2014).

Overall, Central Asian tulips are likely broadly threatened, but the extent and shape of this threat is significantly underreported, especially with regards to the impact of climate change. Strikingly, most species span the borders of the mountains of Central Asia, an ecosystem thought to be particularly vulnerable to the complex impacts of a changing climate (Xenarios et al. 2019; Nowak et al. 2020), and it is of increasing importance to expand upon national efforts to provide a regional perspective on the distribution and threats to wild tulips. This is especially crucial given that new species are frequently described in the region which often have extremely small distributions and may therefore have an immediate risk of extinction (de Groot and Tojibaev 2017; de Groot and Zonneveld 2020). Strikingly the genus Tulipa is only one of many geophytic clades that has a large diversity of species in the region including Amaryllidaceae, the broader Liliaceae of which Tulipa is only a small section, Iridaceae, and Asphodelaceae (Tojibaev et al. 2018). There are also a number of plant communities unique to the region including the walnut-fruit forest (Wilson et al. 2019) and the mountain grasslands (Borchardt et al. 2011). It is therefore likely that the issues surrounding tulips and 
the corresponding threats are not exclusive to this plant group and are broadly indicative of the state of flora in this remote corner of the world.

Here we use species distribution modelling with MaxEnt to examine the range of ten Central Asian tulip species and the predicted changes in habitat suitability linked to climate change. Crucially, this work provides the first regional approach to tulip conservation in Central Asia, showcasing how such a practice can provide a more robust evidence base for conservation decision making in this region.

\section{Methods}

\section{Study site}

Fieldwork for this study was undertaken in the Republic of Kyrgyzstan in the spring of 2019 and 2020. We performed several field surveys: covering south-western Kyrgyzstan specifically the Batken and Osh regions; western Kyrgyzstan specifically the Jalal-Abad and Talas regions; and northern Kyrgyzstan, explicitly the Chuy and Issyk-Kul regions (see Online Resource 1). This fieldwork recorded 85 new location points for the ten species of focus (Table 1). The broader area of Central Asia, specifically the countries of Afghanistan, China, Kazakhstan, Kyrgyzstan, Mongolia, Tajikistan, Turkmenistan, and Uzbekistan, were included in species distribution modelling (Fig. 1).

\section{Species distribution modelling}

MaxEnt v3.4.0, based on the maximum-entropy approach, is a widely used modelling technique, especially in conservation (Trisurat et al. 2013; Liang et al. 2017; Wilson et al. 2019). This software is open source, can model past, present and future species distributions given suitable environmental layers, and relies only on presence data (Phillips et al. 2006). Specifically, the model uses location data and habitat vectors to predict the probability of presence of a species across a selected area. MaxEnt has been used frequently in conservation to model species distributions primarily because it is highly accurate with small sample sizes (Elith et al. 2011; Qin et al. 2017), characteristic of Threatened species. This software also models distributions under future climate change scenarios, allowing this threat to be assessed (Qin et al. 2017; Hof and Allen 2019). MaxEnt's inferences are correlative, with the software using a regression framework to produce predictions of occurrence. This method of climate change modelling often does not provide the same resolution as both mechanistic and trait-based approaches. Yet, these other approaches rely on detailed information of taxon-specific parameters, population sizes, interspecific relationships, and well-defined species distributions (Pacifici et al. 2015). In most cases this type of data is just not available for tulips, or not available in sufficient detail. This is especially the case in Central Asia, which is a relatively data deficient region (Pearson et al. 2014). So, although correlative approaches do not provide the same resolution, they require fewer initial data and therefore can be exceptionally useful for not only modelling present distributions but also future habitat in data poor areas.

In this study we focused on ten Tulipa species representing a range of habitats, distributions, and threat levels. We primarily selected species that had over 20 datapoints available for modelling to ensure there was enough GPS points present to establish a significant relationship with environmental variables. For comparison, we also selected to model $T$. 


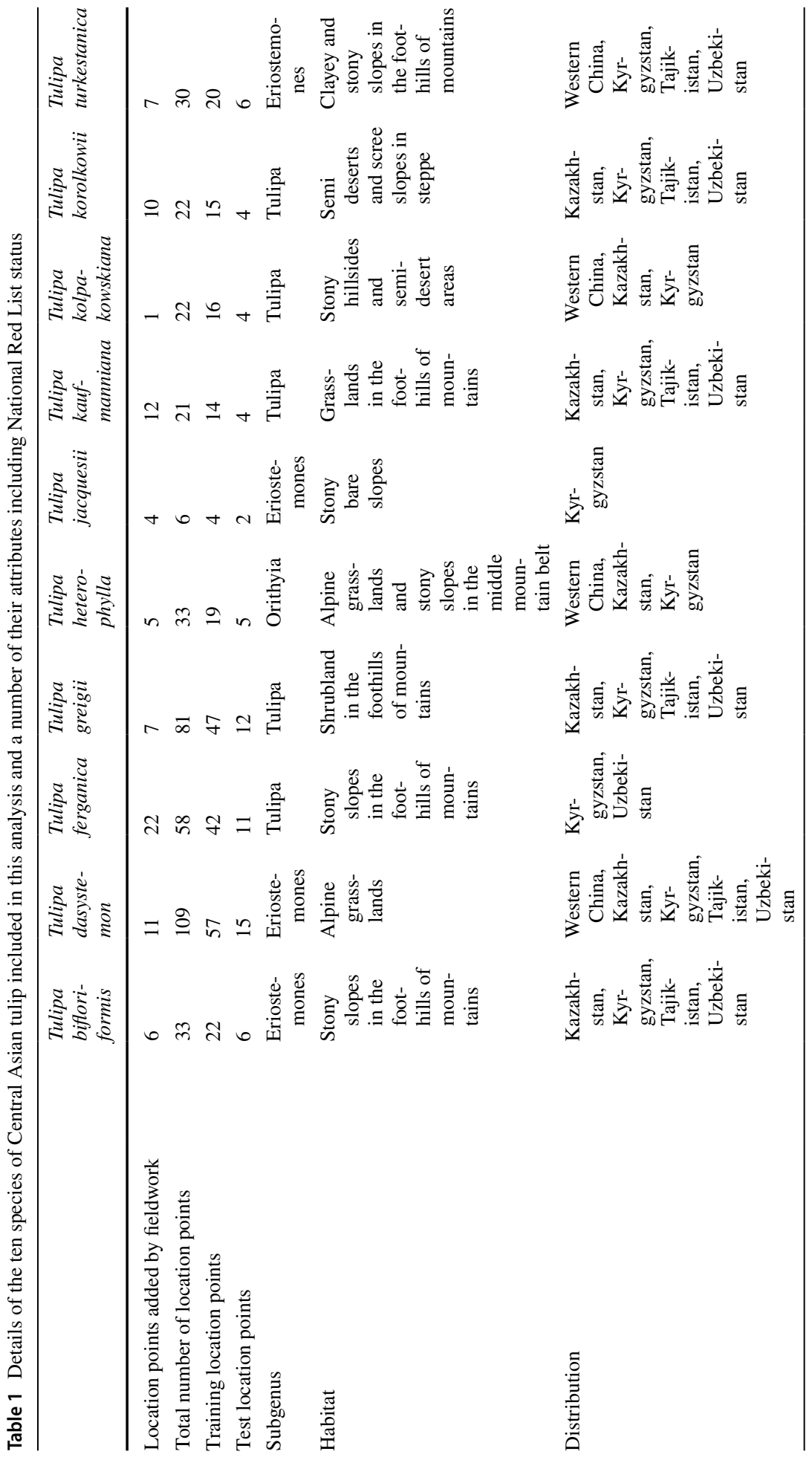




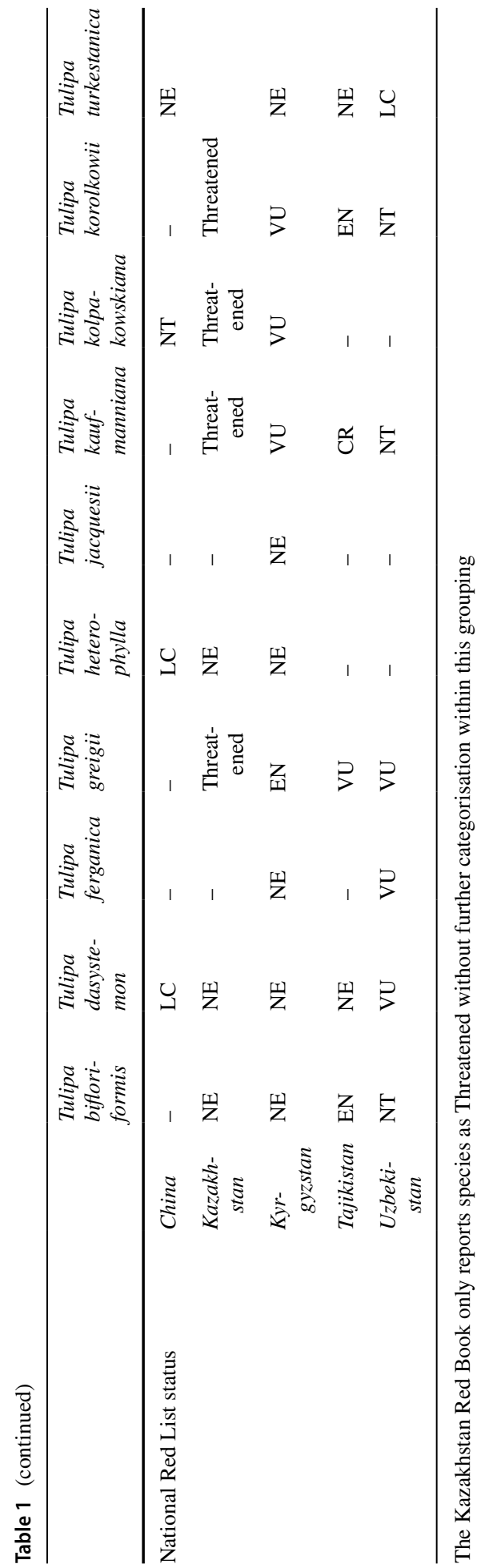



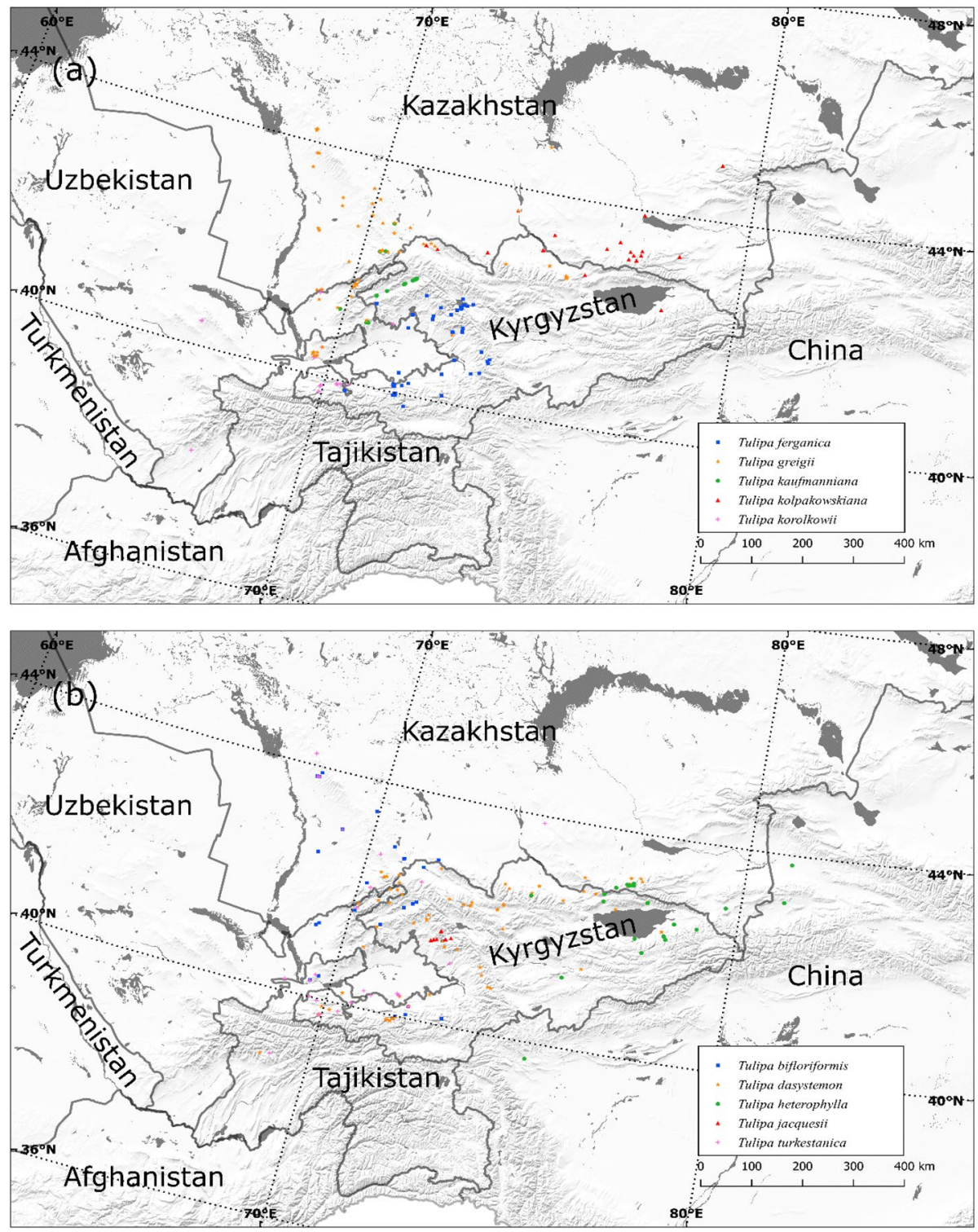

Fig. 1 Map showing the distribution data obtained from GBIF and field surveys used in modelling, projected in Asia North Albers Equal Area Conic coordinate reference system (ESPG 102025)

jacquesii (Zonneveld 2015) as a representative of the recently described endemic species in the region that is relatively data deficient (Table 1). Location data for each species was downloaded from the Global Biodiversity Information Facility (GBIF; GBIF. org 2020) database through the GeoCAT tool (Bachman et al. 2011) and combined with data gathered in our field surveys. We selected 23 environmental variable layers to be used as inputs for the MaxEnt programme. These consisted of 19 bioclimatic layers from the WorldClim 2 database with a resolution of $30 \mathrm{~s}$ or $\sim 1 \mathrm{~km}^{2}$ at the equator (Fick and Hijmans 
2017), high resolution altitude data from the Shutter Radar Topography Mission (SRTM), slope and aspect layers generated from the altitude data using the QGIS 2.14 terrain analysis tool (QGIS Development Team 2009), and the land cover data GlobCover2009 (Arino et al. 2012). These layers have previously been effective in determining the distribution of Threatened species where data are limited, including in Central Asia (Kumar and Stohlgren 2009; Wilson et al. 2019). All layers were checked for multicollinearity using the ENMTools R package (Warren et al. 2019). A single variable from a group of highly correlated variables was chosen for modelling using a threshold ( $\mathrm{r}>0.85)$ commonly applied in MaxEnt work (Syfert et al. 2013; Wilson et al. 2019). We selected the variable from within this group which showed the average highest correlation to all other variables in the group; within this we avoided selecting altitude because this data would be uninformative in any climate modelling as linking a species presence to altitude would not allow for migration of a species.

Multiple location points of a species in the same grid cell were deemed duplicates and were treated as a single point. This reduced the available data for training and testing the model (Table 1). Given the limited data of some species, different modelling features were applied. For species with under ten points we used only linear features, for species with $<25$ points we used linear and quadratic features, whilst for those with $\geq 25$ datapoints linear, quadratic, and hinge features were used in modelling (Elith et al. 2011). K-fold cross-validation $(\mathrm{K}=5)$ was used to generate an average present-day model for each species, as this has been empirically shown to neither be affected by excessively high bias nor very high variance (James et al. 2013) and reported as better than simple thresholding (Merow et al. 2013). The model's accuracy was determined by the test data area under the receiver operating characteristic curve (AUC) value with a value of $>0.9$ representing a very good model, a value between 0.7 and 0.9 showing a good model, and anything with $<0.7$ deemed uninformative (Swets 1988; Baldwin 2009). We assessed a range of regularization multipliers for several species deeming the default (1.0) to be the most effective modelling parameter based on both TestAUC (see Online Resource 2) and current understanding of taxa distributions (Everett 2013), and so this was used in all models. We also generated a dataset of locational data for Liliaceae across Central Asian using GBIF, which we used to perform background manipulation to account for sampling bias (Syfert et al. 2013; Kramer-Schadt et al. 2013). This generally helps to ameliorate overfitting, however, in our case it distorted distributions somewhat, both broadly lowering the TestAUC value (see Online Resource 3) and making predictions of suitable habitat in areas where the species is known not to occur (Everett 2013). We display only present-day modelling efforts and final climate models produced without a bias file. All outputs were presented using a five tier classification system and using the protected area data from Protected Planet (UNEP-WCMC and IUCN 2020).

Climate models were produced for nine of the ten species; T. jacquesii was excluded from this analysis due to its extremely limited location data. Two climate models were selected for comparison, Community Climate System Model version 4 (CCSM4 GCM) and Model for Interdisciplinary Research on Climate (Miroc ESM), to allow us to assess the reliability of our results across models. We selected these as they have both been used in previous studies to assess changes in habitat suitability linked to climate change (Rej and Joyner 2018; Hof and Allen 2019). We also selected two climate change scenarios to model, RCP 2.6 which represents a best-case scenario (BC) where emissions peak in 2020, and RCP 8.5 which is a worst-case scenario and similar to business as usual (BU). We selected to use data from both the years 2050 and 2070 so as to investigate the change in species distribution across multiple future periods. Given the number of models that 
needed to be generated we trained climate models using $75 \%$ of location data and tested them using the remaining $25 \%$ avoiding time consuming five-fold cross-validation (Wilson et al. 2019). All climate models were assessed using the same TestAUC classifications as the present-day models and presented in the same format.

Areas of habitat suitability were calculated for native and non-native sections of the models produced. The native area of a species was estimated based on the model output, location data, and literature (Bachman et al. 2011; Everett 2013; POWO 2019). To capture the native area, we created polygon layers on QGIS covering all location data and connected areas deemed suitable in habitat by the MaxEnt outputs and within or closely adjoining the previous estimated range of the species. We maintained a lenient approach to ensure we did not exclude important parts of the natural distribution from calculations and so likely captured some areas outside of the true distribution of the species. Non-native areas were therefore those outside the range of this polygon. Using these polygons, we extracted the number of cells in each of the five suitable habitat categories for each species. In addition, we used the estimated native areas to extract altitudinal information and calculate protected area coverage. To do this we selected cells from our models with a 0.5 or greater habitat suitability within the predefined natural distribution of the species, and specifically for protected area calculations those that overlapped with recorded protected areas from Protected Planet (UNEP-WCMC and IUCN 2020). We selected this threshold value as it has been previously used in research to represent a presence-absence separation (Carrasco et al. 2020) and would capture areas of habitat deemed to be highly suitable or very highly suitable, which we think represent the most important areas of the species range. To statistically compare altitudinal values from different years, we conducted an analysis of variance (ANOVA), which if significant $(\mathrm{p}<0.05)$ was followed by a Tukey's HSD test. We used the area function of the raster 3.1.5 package (Hijmans 2014) to calculate mean cell size in $\mathrm{km}^{2}$ across the modelled region. We then used this value, $0.648 \mathrm{~km}^{2}$, both for general area calculations as well as alongside the calculated number of cells meeting the threshold criteria to estimate habitat within protected areas. For both altitudinal and area computation raster layers were manipulated on QGIS v2.18.25 (QGIS Development Team 2009) and all calculations were carried out on R v3.4.0 (R Core Team 2020).

\section{Results}

After assessing for multicollinearity, we selected to use 14 layers for present-day modelling, whilst landcover was excluded from any climate modelling as future land cover predictions were not available leaving 13 layers for this aspect (Table 2). All present-day models had TestAUC values larger than 0.9 and were therefore classified as very good (Table 3; Fig. 2). Yet, we report that the distribution of T. jacquesii be used cautiously as only four location points were available to train the model. The most important environmental predictors for every species varied greatly, however, each were linked to precipitation or temperature patterns in the winter or summer months or the seasonality of climate in general (Table 4). Models broadly highlighted areas of mountain ranges in the Tien Shan as suitable habitat, although a few species were more closely linked to semi-desert areas. Some species had relatively extensive distributions across the region, occurring in several mountain ranges, yet there was also several taxa which were much more spatially restricted and occurred in single mountain ranges, valleys, or steppe areas. Our models also show that tulip species are often not spatially separated, with considerable overlap between many 
Table 2 The environmental layers selected, after autocorrelation testing, to be included in the MaxEnt model

\begin{tabular}{ll}
\hline Environmental variable & Source \\
\hline Aspect & Generated in GIS from SRTM Altitude data \\
Slope & Generated in GIS from SRTM Altitude data \\
Mean diurnal range & WorldClim2 (Fick and Hijmans 2017) \\
Isothermality & WorldClim2 (Fick and Hijmans 2017) \\
Precipitation of coldest quarter & WorldClim2 (Fick and Hijmans 2017) \\
Temperature seasonality & \\
Precipitation seasonality & WorldClim2 (Fick and Hijmans 2017) \\
Precipitation of driest month & WorldClim2 (Fick and Hijmans 2017) \\
Precipitation of wettest month & WorldClim2 (Fick and Hijmans 2017) \\
Mean temperature of wettest quarter & WorldClim2 (Fick and Hijmans 2017) \\
Mean temperature of driest quarter & WorldClim2 (Fick and Hijmans 2017) \\
Mean temperature of coldest quarter & WorldClim2 (Fick and Hijmans 2017) \\
Mean temperature of warmest quarter & WorldClim2 (Fick and Hijmans 2017) \\
Land cover & GlobCover 2009 (Arino et al. 2012) \\
\hline
\end{tabular}

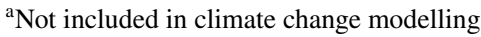

species' ranges. All species modelled, barring T. jacquesii as its model was deemed unreliable, were predicted to occur in at least one protected area. Nonetheless five species had less than five percent of their range in protected areas and both T. korolokowii and T. ferganica had two percent or less captured in the protected area network (Fig. 3).

For climate modelling, all models had TestAUC values greater than 0.9 and were deemed 'very good' providing informative results (Table 3). We present only the results from the CCSM4 GCM modelling (Fig. 4) as the results of Miroc ESM were consistently similar to CCSM4 GCM models not only across climate scenarios, but also years, and taxa (see Online Resource 4). There were two species reported that appeared to retain or expand in suitable habitat area, T. biflorformis and T. kaufmanniana, however, much of the future suitable habitat area for these species occurred in the Pamir mountains of Tajikistan, an area hundreds of kilometres from their native range. Given this information all models consistently showed a considerable reduction in the size of suitable habitat for tulip species in their natural distribution (Table 5; Fig. 5; see Online Resource 5). The suitable habitat area in the native species range of T. bifloriformis, T. dasystemon, T. greigii, and T. kaufmanniana declines in a stepwise manner from present-day to 2050 to 2070 , with on average $78 \%$ of high and very high suitable habitat areas lost by 2050 and $83 \%$ lost by 2070 . Whilst suitable habitat for the semi-desert dwelling species, T. korolkowii and T. kolpakowskiana and the alpine species of T. turkestanica, T. heterophylla, and T. ferganica is predicted to disappear completely. Overall, BC and BU scenarios were broadly similar however generally BU scenarios showed marginally less suitable habitat than the BC scenarios (Fig. 4).

Under future climate scenarios protected area coverage in the species native range decreased for all species except $T$. bifloriformis. For seven out of the nine modelled species coverage dropped to below one percent by 2050 and for six no suitable habitat was protected (Fig. 3; see Online Resource 6). Our analyses also revealed that there was a significant difference between the mean altitude (metres) between the present day, 2050 and 2070 for $T$. bifloriformis $\left[\mathrm{F}(2,296,712)=224,119, \mathrm{p}<2.2 \times 10^{-16}\right], T$. 


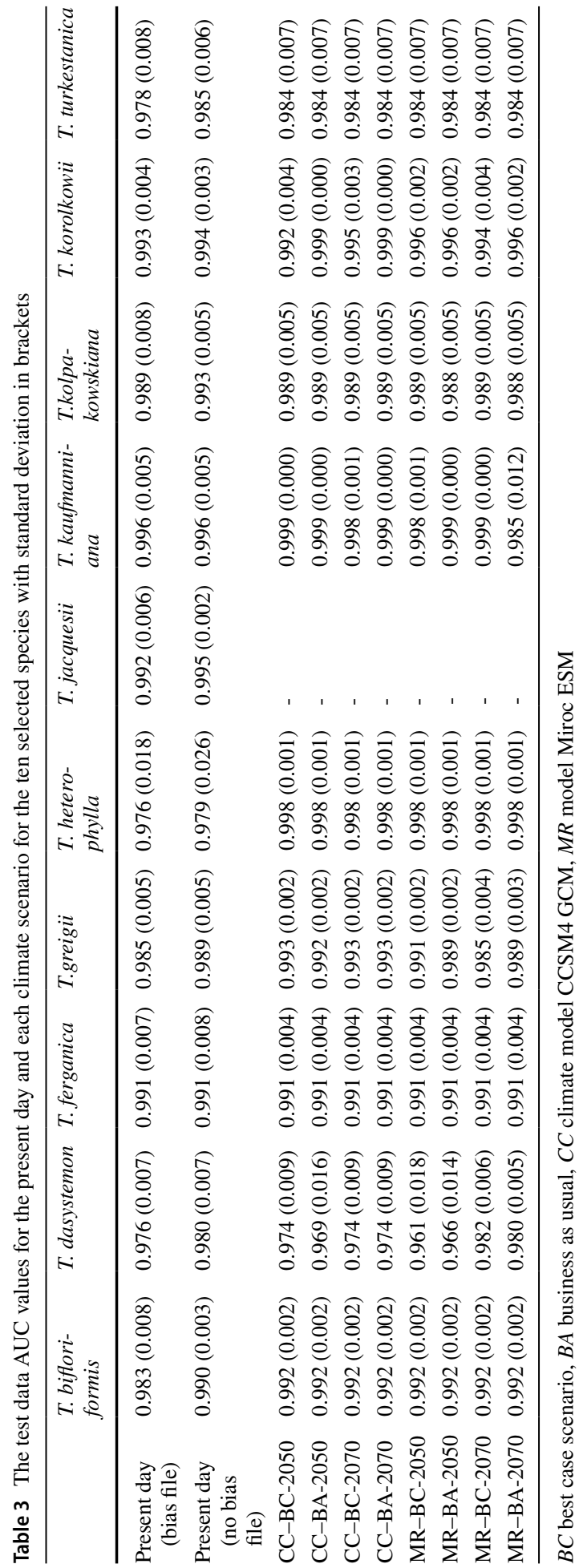



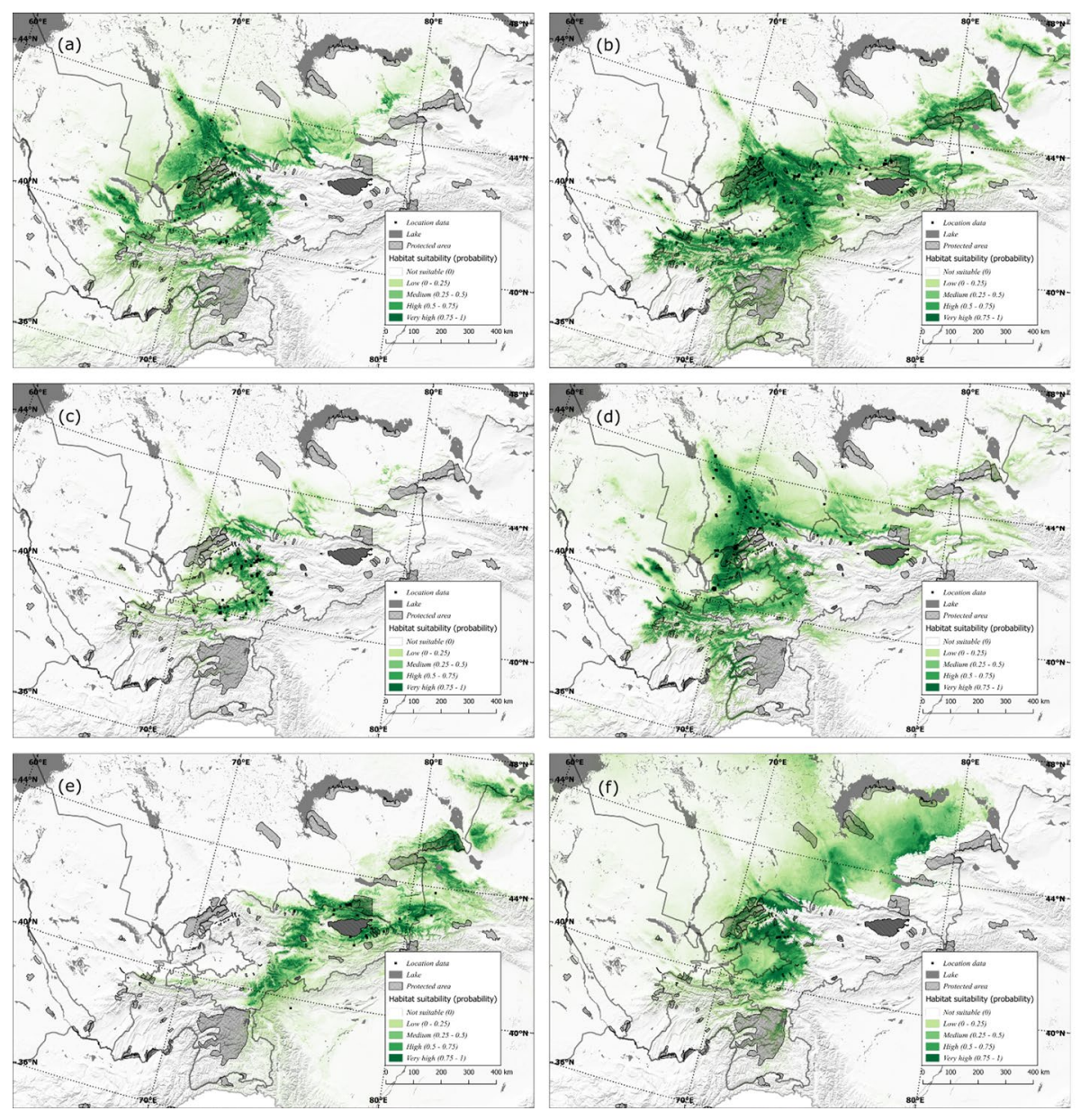

Fig. 2 MaxEnt Species distribution models produced without a bias file projected in Asia North Albers Equal Area Conic coordinate reference system (ESPG 102025) with cell size of $\sim 0.65 \mathrm{~km}^{2}$. Panels correspond to different species: a T. bifloriformis, $\mathbf{b}$ T. dasystemon, $\mathbf{c}$ T. ferganica, $\mathbf{d} T$. greigii, $\mathbf{e}$ T. heterophylla, $\mathbf{f}$ T. jacquesii, $\mathbf{g}$ T. kaufmanniana, $\mathbf{h}$ T. kolpakowskiana, $\mathbf{i}$ T. korolkowii, and $\mathbf{j}$ T. turkestanica

dasystemon $\left[\mathrm{F}(1,226,007)=16.098, \mathrm{p}=6 \times 10^{-5}\right]$, T. greigii $[\mathrm{F}(2,145,406)=2280.6$, $\left.\mathrm{p}<2.2 \times 10^{-16}\right]$, and T. kaufmanniana $\left[\mathrm{F}(2,36,941)=29,635, \mathrm{p}<2.2 \times 10^{-16}\right]$ (Fig. 6; see Online Resource 7). More specifically, the altitudinal range significantly narrowed in future years for all species, whilst the suitable habitat areas for T. bifloriformis, $T$. dasystemon, and T. kaufmanniana were predicted to shift to higher altitudes. Surprisingly and unlike these other species the suitable habitat for T. greigii in 2050 was predicted to occur on average at lower altitudes than the present day, specifically at the base of previously more broadly suitable mountains. Nonetheless, the area of suitable habitat in 2070 was then predicted to shift back to near the present day mean altitude. All comparisons between years for these four species were deemed significant through a post-hoc TukeyHSD test (Table 6). 

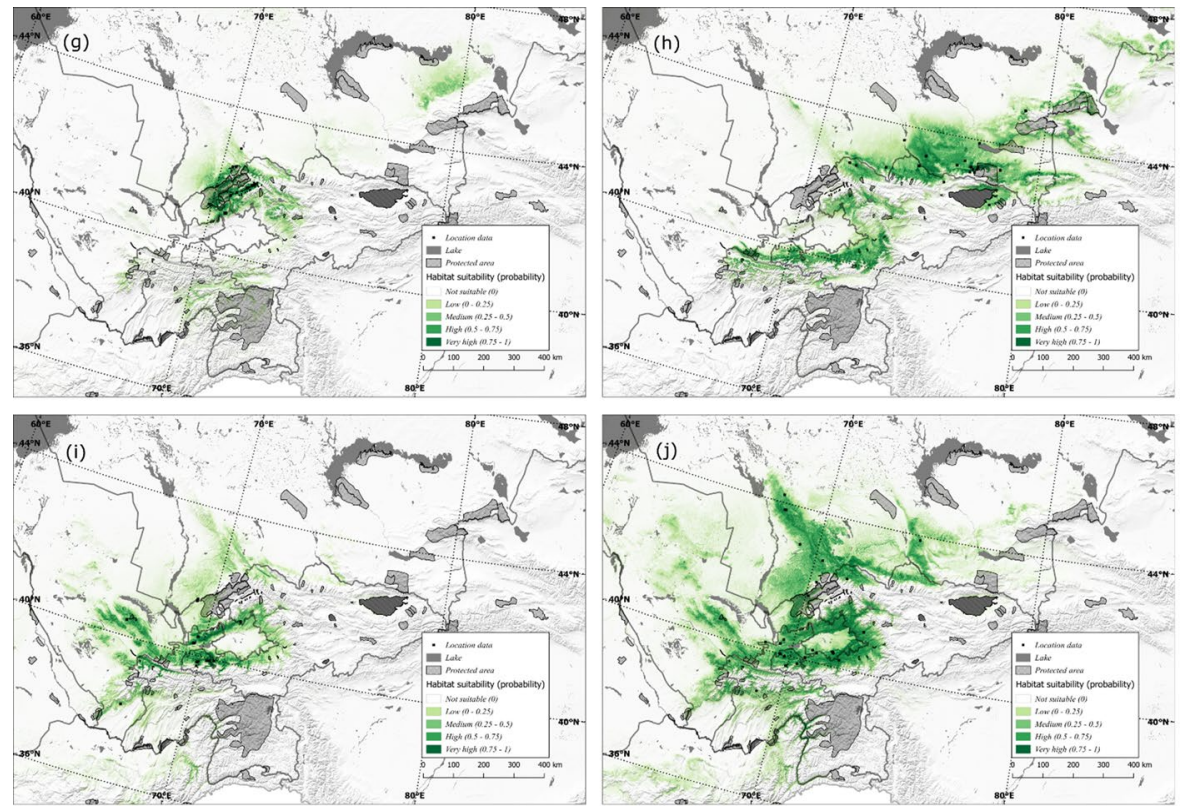

Fig. 2 (continued)

\section{Discussion}

Central Asia is the primary diversity hotspot for wild tulips and many species in this region have an elevated risk of extinction. Several new species have recently been described with highly restricted ranges. However, distributional understanding of tulips across this area is often poor and threats are inadequately reported. This study is the first to take a regional level approach to model current distributions of Tulipa, including one newly described endemic species, and assess how habitat suitability may change under different climate scenarios. Our models highlight a range of important results both for present day modelling as well as under future climate scenarios that allows us to draw a number of conclusions, primarily about tulips, with implications for the wider plant community and conservation. We recognise the limitation of modelling approaches to current and future species distributions, nonetheless our models provide an important resource, especially to aid future Red Listing efforts for the Tulipa genus, and to guide appropriate conservation interventions.

First, our models showcase the tight link between most Central Asian tulip's distributions and the mountain ranges of this region in both current and future climate scenarios. Our work underscores the importance of mountains in the niche occupancy of tulips in line with previous studies (Botschantzeva 1982). Far fewer species inhabit the lowland steppes and semi-desert areas of the region (Everett 2013), and so although these may still be of importance for conservation efforts, targeting mountainous areas is more urgent given the limited resources available to conservation practitioners (Bottrill et al. 2008). Moreover, our models highlight that many species distributions overlap across these alpine areas. This includes a number that are superficially similar showcasing 
Table 4 The most significant variables that contributed to each species present day model

\begin{tabular}{|c|c|c|c|}
\hline & Variable & $\begin{array}{l}\text { Percent contribu- } \\
\text { tion }\end{array}$ & $\begin{array}{l}\text { Permutation } \\
\text { importance }\end{array}$ \\
\hline \multirow[t]{2}{*}{ T. bifloriformis } & Precipitation of coldest quarter & 38.6 & 5.3 \\
\hline & Precipitation seasonality & 2.5 & 60.3 \\
\hline \multirow[t]{2}{*}{ T. dasystemon } & Precipitation of driest month & 27 & 22.4 \\
\hline & Precipitation of wettest month & 4.5 & 50.7 \\
\hline \multirow[t]{2}{*}{ T. ferganica } & Precipitation of coldest quarter & 22.1 & 0.2 \\
\hline & Precipitation seasonality & 6.5 & 66.8 \\
\hline \multirow[t]{2}{*}{ T. greigii } & Precipitation of coldest quarter & 22.1 & 0.7 \\
\hline & Precipitation seasonality & 10.2 & 44.5 \\
\hline \multirow[t]{2}{*}{ T. heterophylla } & Precipitation of driest month & 23.2 & 31.4 \\
\hline & Precipitation of wettest month & 5.7 & 38.3 \\
\hline \multirow[t]{2}{*}{ T. jacquesii } & Precipitation seasonality & 39.9 & 62.9 \\
\hline & - & - & - \\
\hline \multirow[t]{2}{*}{ T. kaufmanniana } & Precipitation of coldest quarter & 32.7 & 13 \\
\hline & Precipitation seasonality & 10.5 & 60.4 \\
\hline \multirow[t]{2}{*}{ T. kolpakowskiana } & Precipitation of driest month & 25.9 & 2.4 \\
\hline & Mean temperature of coldest quarter & 6.9 & 39.3 \\
\hline \multirow[t]{2}{*}{ T. korolkowii } & Mean temperature of driest quarter & 26.8 & 8.1 \\
\hline & Mean temperature of coldest quarter & 11.8 & 68.6 \\
\hline \multirow[t]{2}{*}{ T. turkestanica } & Mean temperature of driest quarter & 33 & 2.3 \\
\hline & Mean temperature of coldest quarter & 9 & 55.1 \\
\hline
\end{tabular}

Reported are those that had the greatest reported percent contribution and permutation importance. If second row is empty the variable reported in the first row had the largest percent contribution and permutation importance

the taxonomic difficulties of this genus, which are so often reported (Zonneveld 2009; Christenhusz et al. 2013). Given this, we urge researchers to be cautious when using tulip location data, especially where not supported by herbarium specimens, as well as our models and to critically assess these based on the current known natural distributions. This identification problem is exacerbated by the inconsistent use of the taxonomy of tulips (Christenhusz et al. 2013). We currently recommend using the species concepts of Christenhusz et al. (2013) so as to ensure consistent use of names across the scientific community, until further taxonomic work can update species concepts, which we note is urgently needed.

Many of the transnational species modelled in this project are reported Threatened across parts of their range. Yet, our results highlight that, frequently, the countries in which they are reportedly most Threatened often harbour only a small proportion of the overall distribution, and potential distributions under climate change. This is especially apparent for T. bifloriformis, T. korolkowii and T. kaufmanniana which are recorded in Tajikistan as Endangered, Endangered, and Critically Endangered respectively, yet they are recorded in an exceptionally small area of northern Sughd region, which may represent the extremity of their range. Nonetheless, this is also the case for other species such as $T$. greigii and $T$. dasystemon. This trend highlights that relying on national assessments for an understanding of the extinction risk of the whole species may be misleading and that global 

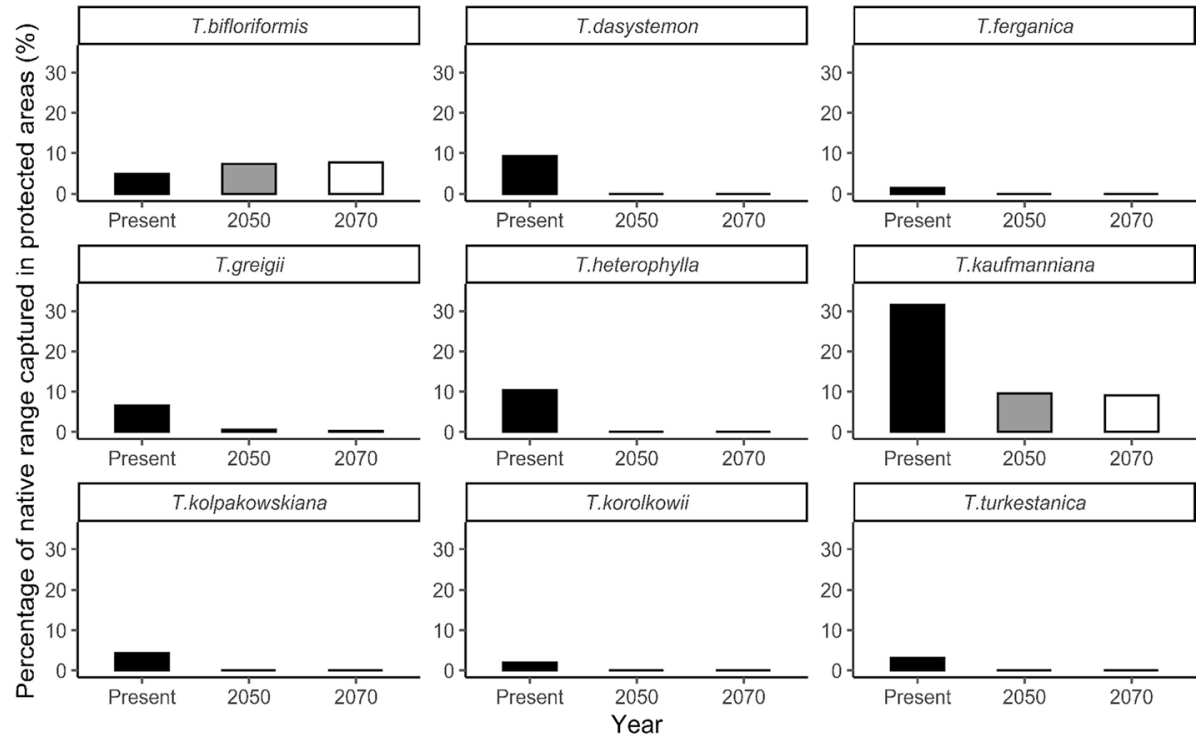

Fig. 3 Bar chart showing the percentage of species high and very high native suitable habitat area captured within protected areas across present day, 2050, and 2070
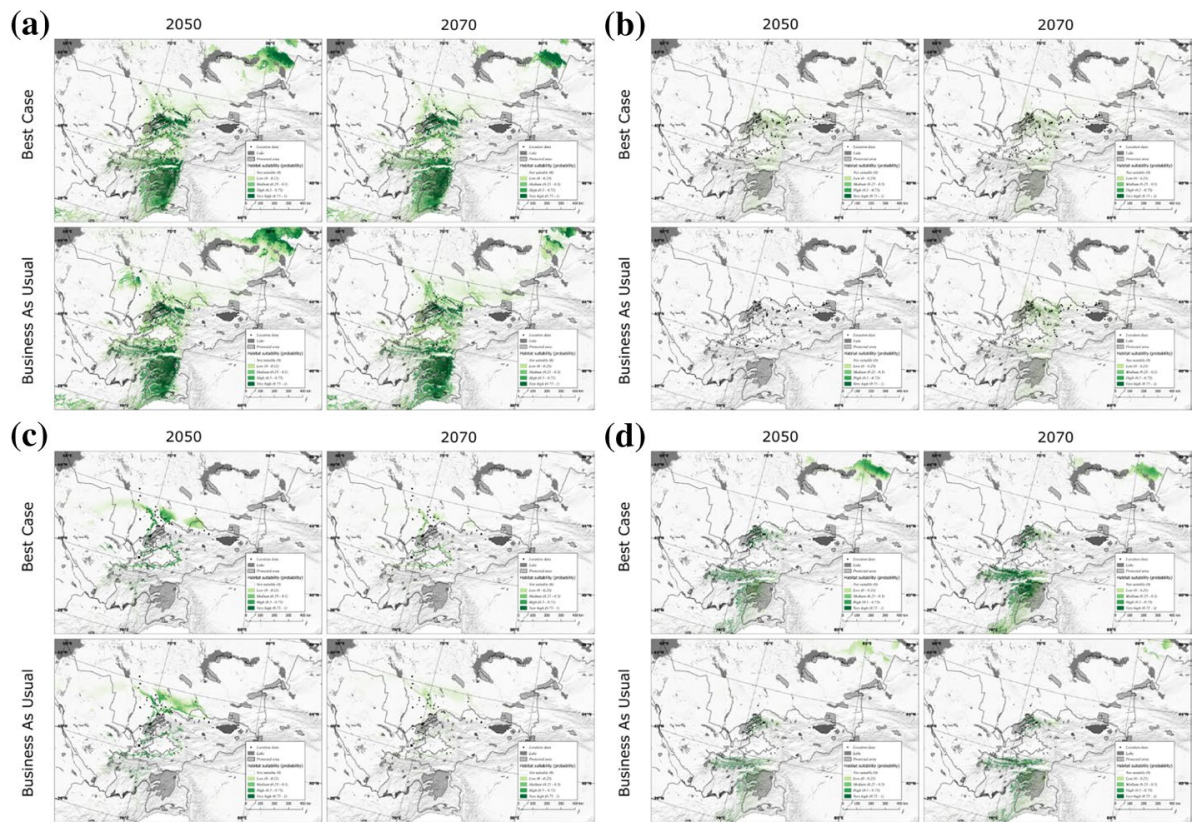

Fig. 4 Climate modelling outputs showing suitable habitat for four species a T. bifloriformis, b T. dasystemon, c T. greigii, and d T. kaufmanniana under best case and business as usual CCSM4 GCM models projected in Asia North Albers Equal Area Conic coordinate reference system (ESPG 102025) with cell size of $\sim 0.65 \mathrm{~km}^{2}$ 


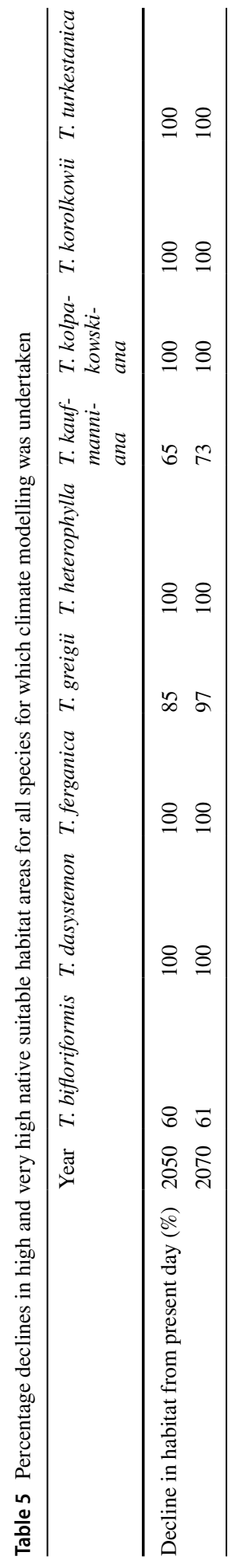



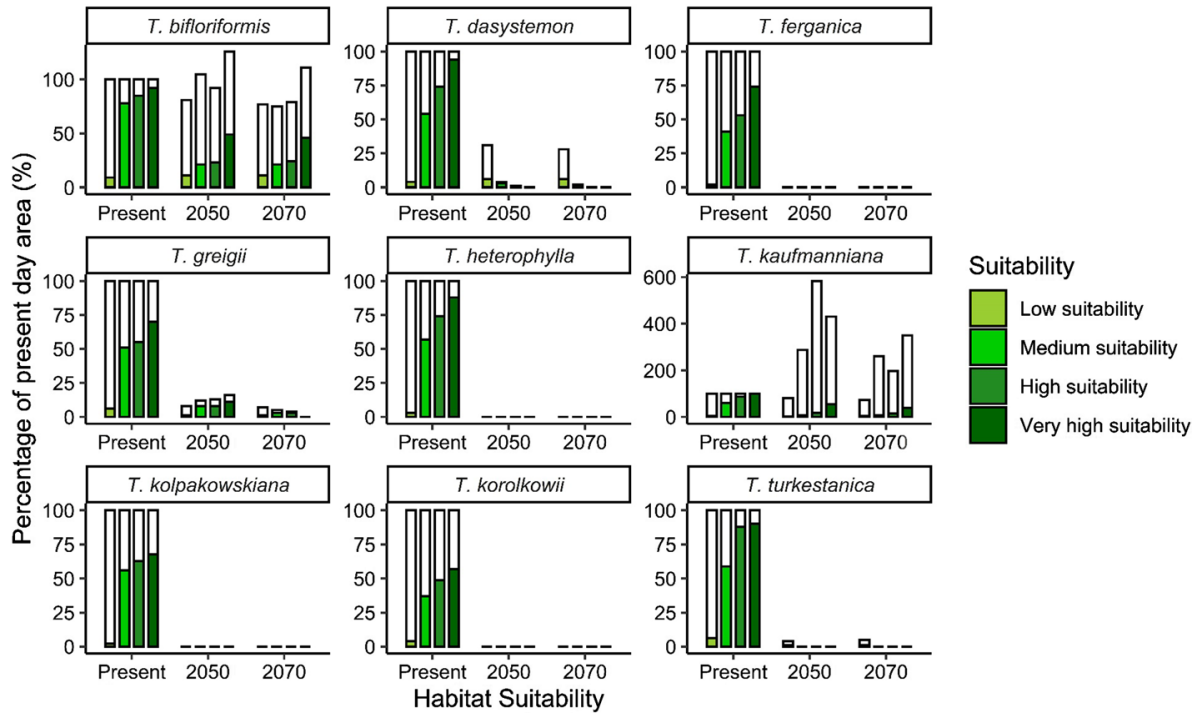

Fig. 5 Bar chart showing the percentage of the present-day suitable habitat area remaining across presentday, 2050, and 2070 for nine species under climate modelling. White bars represent non-native areas and coloured bars represent native areas with different shades representing degrees of habitat suitability. N.B. T. kaufmanniana graph has a y-axis that extends to $600 \%$ because large areas outside of the natural habitat became suitable under future climate scenarios

assessments provide a much more informative and reliable approach. Nevertheless, remote regions of a species' distribution must still be considered in conservation planning as they potentially represent important sites of local adaptation and therefore genetic novelty (Flanagan et al. 2018). We also note through our work that several species are not evaluated in countries where they are reported as native, for example T. dasystemon in Kyrgyzstan. This is often because the species is widespread and national documents only focus on Threatened species (SAEPF et al. 2006). However, many of these taxa are considered Threatened elsewhere in their range e.g., T. dasystemon is Vulnerable in Uzbekistan. National level assessments may therefore present species as Threatened and in need of urgent action when across their broader range they could be considered relatively secure. Our work reinforces that although national level information remains an important resource, it needs to be critically assessed and considered in a broader context for use in directing conservation actions for non-endemic species. Furthermore, our climate models show that suitable habitat in future scenarios will remain trans-national and so international efforts will be crucial for tackling the impacts of climate change in Central Asia.

Due to its recent description, the endemic T. jacquesii, unlike the other species modelled here, had very limited location data available. We decided to model this species even given its limited GPS data to present an understanding of the challenges associated with a newly described taxon, as in the past decade a number of new tulip species have been described representing a considerable degree of newly discovered diversity (Tojibaev et al. 2014; de Groot and Tojibaev 2017; de Groot and Zonneveld 2020). Currently, like T. jacquesii, these taxa generally lack location information and conservation assessments. Our modelling of $T$. jacquesii supports previous research suggesting that predicting distributions with the extremely low number of points is highly constrained (Pearson et al. 2007); 


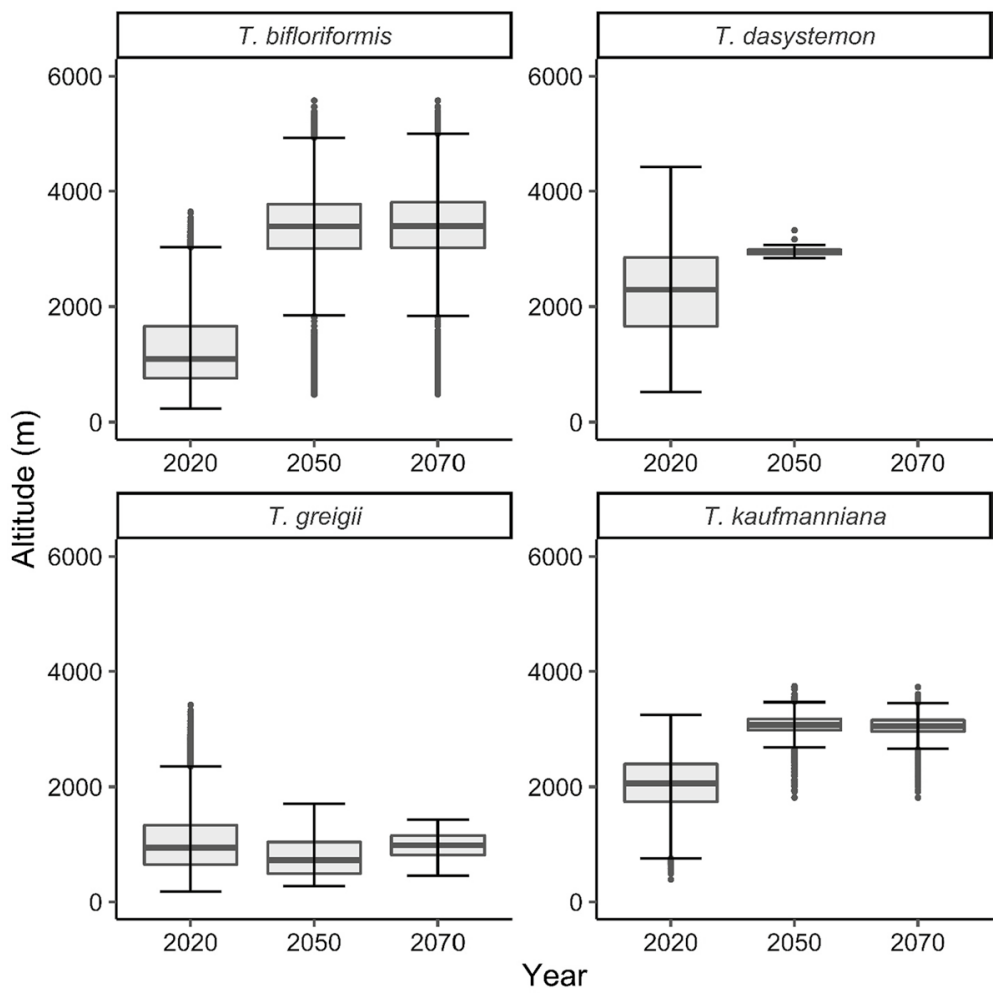

Fig. 6 Boxplots showing the altitudinal range encompassed in high and very high suitable habitat areas for the four species with predicted suitable habitat in future climate scenarios

Table 6 Statistical results of TukeyHSD test for altitudinal range of highly suitable habitat areas across present day, 2050, and 2070 under the CCSM4 GCM model

\begin{tabular}{llllll}
\hline & Year comparison & $\begin{array}{l}\text { Estimated } \\
\text { difference } \\
(\mathrm{m})\end{array}$ & $\begin{array}{l}\text { 95\% confidence } \\
\text { interval for mean } \\
\text { lower bound }(\mathrm{m})\end{array}$ & $\begin{array}{l}\text { 95\% confidence } \\
\text { interval for mean } \\
\text { upper bound }(\mathrm{m})\end{array}$ & $\mathrm{p}$ value \\
\hline T. bifloriformis & $2020-2050$ & 2003 & 1994 & 2011 & $<0.0005$ \\
& $2020-2070$ & 2033 & 2024 & 2042 & $<0.0005$ \\
& $2050-2070$ & 30 & 20 & 41 & $<0.0005$ \\
T. dasystemon & $2020-2050$ & 721 & 369 & 1074 & $<0.0005$ \\
T. greigii & $2020-2050$ & -251 & -260 & -242 & $<0.0005$ \\
& $2020-2070$ & -74 & -95 & -53 & $<0.0005$ \\
& $2050-2070$ & 177 & 155 & 199 & $<0.0005$ \\
T. kaufmanniana & $2020-2050$ & 1020 & 1008 & 1031 & $<0.0005$ \\
& $2020-2070$ & 999 & 986 & 1013 & $<0.0005$ \\
& $2050-2070$ & -20 & -36 & -5 & $<0.01$ \\
\hline
\end{tabular}


in our case the predicted range was much larger than expected. Our work therefore importantly highlights the need for efforts to explore distributions for recently described tulip species to enable more accurate modelling and assessment of true distribution size. This forms part of a broader need for more information about these species to facilitate reliable assessment of their conservation status. Our T. jacquesii model provides a resource to aid in the search for new populations of this endemic species (Fois et al. 2018), albeit lacking significant resolution.

Protected areas remain essential to conservation efforts globally (Naidoo et al. 2019), as reflected in policy in the Aichi Biodiversity Targets (Venter et al. 2014), and present a useful tool for safeguarding tulip populations. Using our models, we explored the overlap between predicted distributions and coverage of protected areas. Overall, this work emphasises the poor coverage of the protected area network of Central Asia in capturing tulip diversity. In general, most species have only been reported in one protected area (GBIF. org 2020) and our models support the view that only small parts of most species' distributions are captured in this network. Nonetheless our models do highlight that most species likely occur in several protected areas, but not always with confirmatory location data. Further efforts are needed to document the presence of species in many protected areas across the region. For example, our models of the species T. korolkowii and T. ferganica underline the restricted representation of these taxa in protected areas. Current knowledge also suggests that $T$. jacquesii does not occur in any protected areas, yet our model lacks the resolution to confidently assess this. Given the importance of protected areas for plant conservation (Chape et al. 2008; Souza and Prevedello 2020), the limited coverage provided for Threatened tulips needs to be addressed. Here, our models together with previous work (Botschantzeva 1982; Everett 2013) show that large areas of suitable habitat for these species are situated away from settlements in remote mountainous areas where increased protected area coverage may be feasible (Venter et al. 2018). These remote areas form part of the broader Mountains of Central Asia biodiversity hotspot (Critical Ecosystem Partnership Fund 2016) and so protection of these habitats may improve the survival chances of an array of Threatened species (Nowak et al. 2020). Even so, it is important to recognise that protection of lowland areas, especially semi-desert areas, will clearly also be essential for conserving species such as $T$. korolkowii, that are currently overly exposed to extinction due to the significant underrepresentation of their habitat in the Central Asian protected area network. Importantly, protected areas will not offer a silver bullet, with populations known to have declined in some strictly protected reserves (Krasovskaya and Levichev 1986), therefore a combination of conservation actions will need to be put in place alongside a strengthened protected area network. Regular monitoring of populations and stronger enforcement of environmental laws will also be critical components of successful implementation.

We undertook climate change modelling of this region to offer the first ever perspective on how this threat may impact future tulip habitat suitability. Across all models, seasonality, and precipitation or temperature patterns in the winter or summer months were deemed important predictors of distribution and this emphasises the importance of seasonal triggers in the life cycle of tulips (Botschantzeva 1982). Broadly, our models show that areas of habitat suitability will decline in all species including even the widely distributed and relatively common species, such as $T$. dasystemon, which exhibit a significant loss of suitable habitat in their native range. The severity of these declines is captured most clearly for T. bifloriformis which showed the lowest recorded loss of native habitat under future climate scenarios, yet even in this species only $40 \%$ of the present-day area of 'high' and 'very high' suitable habitat areas was predicted to remain in 2050. Clearly, climate 
change poses a significant threat to all tulip diversity in this region, mirroring the situation of many plants worldwide (Parmesan and Hanley 2015). We note that BA models were broadly worse than $\mathrm{BC}$ and so climate change mitigation may play a role in tulip conservation, but our models emphasise the severe plight of tulips even under best case climate scenarios. Although there is uncertainty surrounding our models, they reveal that distinct tulip habitats vary in vulnerability to climatic shifts. For example, our work shows that all semi-desert and steppe dwelling species are predicted to see a complete loss of suitable habitats by 2050, whereas only some alpine species show this. This is likely due to changes in rainfall patterns across these areas with aridity predicted to increase (Lioubimtseva and Henebry 2009). Given this information there is an urgent need to better protect populations of these semi-arid species now to allow genetic diversity to develop that may enable better resilience to climate change impacts in the future (Jump and Peñuelas 2005). Suitable habitat for some alpine species undergoes observable shifts to higher altitudes and declines in a stepwise manner as time progresses. This shift in altitude has been previously observed in different plant groups (Lenoir et al. 2008), but we provide supporting evidence that some tulip species may also show similar migratory trends. Our models suggest that this will also increase fragmentation of alpine refuges, leading to reduced gene flow between populations and an increased risk of extinction (Halloy and Mark 2003) escalating the need for more targeted conservation actions.

Protected areas and their expansion would likely play a significant role in the conservation of some species under future climate scenarios. Mountainous areas, including the mountains of Central Asia, are predicted to be extremely sensitive to the impacts of climate change (Rangwala and Miller 2012), yet across Central Asia there are a number of protected areas that encompass high altitudinal habitat, which notably are already connected to landscapes where tulips grow. Broadly our modelling shows that protected area coverage of species will decrease under future climate scenarios yet, they also suggest that several protected areas already encompass suitable habitat into which tulips may eventually migrate and so could be of increasing importance to populations as climate patterns begin to change. As an exception to this rule, T. bifloriformis appears to have more suitable habitat in protected areas in future climate scenarios. Even so, given the poor dispersal range of tulips (Kashin et al. 2016), a trait deemed important for survival in alpine areas (Rumpf et al. 2019), migration may be slow and could prevent species from reaching suitable habitat areas before dying out. There is already significant evidence that extinction debts and colonisation credits will be widespread in future climate change scenarios in mountainous regions (Rumpf et al. 2019). So, although several alpine tulips are predicted to have suitable habitat at higher altitudes, including within protected area, their survival may still rely on human intervention. Interestingly, suitable areas way outside of several species natural ranges were highlighted in our modelling. This was especially apparent for T. kaufmanniana and $T$. bifloriformis, whose native range currently encompasses the mountains around the Fergana valley, but where large parts of Tajikistan's more southerly Pamir mountains became suitable in 2050 and 2070. We therefore suggest that future species translocation initiatives (Berger-Tal et al. 2020) may be necessary, although considerable further work is needed to determine the effectiveness and ecological safety of such an action.

We note here that our models do not account for a range of factors. Genetic variation and species adaptability to climate change has not been incorporated, but can be important for persistence in areas deemed unsuitable (Graae et al. 2018; Razgour et al. 2019). Moreover, previous research has shown tulips can actively populate and survive in highly disturbed landscapes including agricultural land (Krasovskaya and Levichev 1986; Pratov et al. 2006) and therefore may survive better in a changing landscape than 
our models predict. Although changes in climate may decouple seasonal triggers such as flowering time (Wadgymar et al. 2018) which could be exceptionally damaging for tulips and similar plants that rely heavily on these for the timing of their short growing season. Furthermore, alpine habitats encompass a range of microclimatic niches which broad scale modelling overlook as potential refuge areas (Scherrer and Körner 2011). Some areas deemed unsuitable may therefore in fact present adequate microclimatic conditions for the survival of local populations. The structural composition of communities, which is especially important to tulips due to their requirement for direct sunlight for growth, may mean that areas within predicted suitable habitat cannot in fact support populations (Vittoz et al. 2009). We therefore acknowledge these limitations and accept that some taxa may be more resilient than suggested by our models. Nonetheless, we suggest climate change will be an important threat to tulip populations, and highlight that there are other factors we have not examined, such as the shifting of invasive species into mountainous areas, that could exacerbate impacts further (Petitpierre et al. 2016).

Climate change is not the only threat posed to wild tulip species. Poorly managed livestock can cause significant damage to ecosystems (Wilson et al. 2019) and livestock overgrazing continues to degrade habitat across much of Central Asia (Tojibaev and Beshko 2015; Nowak et al. 2020). Given that livestock populations are thought to be on the increase across Central Asia, overgrazing appears to pose a growing threat to tulips. Furthermore, although many settlements are in rural areas (Djanibekov et al. 2016) urbanisation also poses a threat to tulips. Many of the major cities in Central Asia are situated close to mountainous tulip habitat, including Bishkek, Almaty, Dushanbe, and Samarkand. Given the rapid development of these cities and the corresponding loss of habitat, urbanisation needs to be urgently considered as part of any tulip conservation activities in the region; a similar but more localised threat is presented by mining activities. Finally, the horticultural history of the genus and the demand for tulips worldwide has meant that wild collection and trade has been reported as a threat and is believed to have led to previous extinctions and populations declines (Maunder et al. 2001; Menteli et al. 2019). Central Asian tulips have been an important part of tulip horticulture throughout the existence of this trade (Christenhusz et al. 2013) and now many Threatened tulip species are protected by law (SAEPF et al. 2006). Yet, opportunistic collection continues, and this may exacerbate the impact of other threats including climate change.

Overall, here we have shown that climate change will pose a significant threat to wild tulips, whilst current distributions of most species are tightly linked to the mountains of the broader Central Asia region and are poorly captured in protected areas. This leaves many populations already declining, spanning borders that scientific research and conservation collaboration has not yet bridged, and increasingly exposed to an array of threats and their interactions. Whilst our work has focused on the genus Tulipa, and specifically Central Asian species, we recognise that many plant groups require similar focused attention and so, although we advocate for urgent efforts to protect wild tulips from growing threats, we also suggest that efforts are made to carefully assess and use available data, including national level assessments, to improve conservation of plants across broader Central Asia. Yet, most importantly in this paper we have shown that a regional approach is essential for an accurate understanding of a species' risk of extinction, especially with respect to the growing impacts of climate change. Given this, now is the time for the broader conservation community to work together to ensure a more aligned regional approach in Central Asia. 
Supplementary Information The online version contains supplementary material available at https://doi. org/10.1007/s10531-021-02165-z.

Acknowledgements This work would not have been possible without the expertise of Jarkyn Samanchina, Akylai Kabaeva, and David Gill who helped with expedition planning and supported on the ground efforts. The broader team at Fauna \& Flora International provided technical support throughout also, which we are most grateful for. We thank members of the Brockington Lab for discussion, advice, and critical reading of the manuscript. We also thank the two anonymous reviewers for their constructive criticism of the paper. Financial support for this project was provided by NERC DTP PhD project of BW and SFB, the Finnis Scott Foundation to FFI, and a Darwin Initiative to FFI and SFB.

Author contributions BW aided in project design, data collection, data analysis, writing, and revisions of the manuscript. AD aided in data collection. BB aided in data analysis and revisions of the manuscript. CC aided in project design and revisions of the manuscript. GL aided in data collection and revisions of the manuscript. KS aided in project design, data collection and revisions of the manuscript. MG aided in data collection. OS aided in data collection and revisions of the manuscript. SB aided in project design, writing, and revisions of the manuscript.

Funding This project was supported by a NERC DTP PhD project of BW and SFB (PDAG/437), part funded through a Darwin Project Grant to FFI and SFB (Ref: 26020) and aided by a grant from the Finnis Scott Foundation to FFI.

\section{Declarations}

Conflict of interest There are no conflicts of interest reported for any of the authors.

Open Access This article is licensed under a Creative Commons Attribution 4.0 International License, which permits use, sharing, adaptation, distribution and reproduction in any medium or format, as long as you give appropriate credit to the original author(s) and the source, provide a link to the Creative Commons licence, and indicate if changes were made. The images or other third party material in this article are included in the article's Creative Commons licence, unless indicated otherwise in a credit line to the material. If material is not included in the article's Creative Commons licence and your intended use is not permitted by statutory regulation or exceeds the permitted use, you will need to obtain permission directly from the copyright holder. To view a copy of this licence, visit http://creativecommons.org/licenses/by/4.0/.

\section{References}

Arino O, Ramos Perez JJ, Kalogirou V, et al (2012) Global Land Cover Map for 2009 (GlobCover 2009). PANGAEA

Bachman S, Moat J, Hill AW et al (2011) Supporting Red List threat assessments with GeoCAT: geospatial conservation assessment tool. Zookeys. https://doi.org/10.3897/zookeys.150.2109

Baitulin IO (2014) Red Data Book of Kazakhstan. Volume 2: Plants. AprPrintXXI, Astana, Kazakhstan

Balding M, Williams KJH (2016) Plant blindness and the implications for plant conservation. Conserv Biol 30:1192-1199. https://doi.org/10.1111/cobi.12738

Baldwin RA (2009) Use of maximum entropy modeling in wildlife research. Entropy 11:854-866. https://doi.org/10.3390/e11040854

Berger-Tal O, Blumstein DT, Swaisgood RR (2020) Conservation translocations: a review of common difficulties and promising directions. Anim Conserv 23:121-131. https://doi.org/10.1111/acv.12534

Borchardt P, Schickhoff U, Scheitweiler S, Kulikov M (2011) Mountain pastures and grasslands in the SW Tien Shan, Kyrgyzstan - Floristic patterns, environmental gradients, phytogeography, and grazing impact. J Mt Sci 8:363-373. https://doi.org/10.1007/s11629-011-2121-8

Botschantzeva Z (1982) Tulips: taxonomy, morphology, cytology, phytogeography and physiology, Translated. A. A. Balkema, Rotterdam

Bottrill MC, Joseph LN, Carwardine J et al (2008) Is conservation triage just smart decision making? Trends Ecol Evol 23:649-654. https://doi.org/10.1016/j.tree.2008.07.007 
Carrasco J, Price V, Tulloch V, Mills M (2020) Selecting priority areas for the conservation of endemic trees species and their ecosystems in Madagascar considering both conservation value and vulnerability to human pressure. Biodivers Conserv 29:1-14

Chape S, Spalding M, Jenkins MD (2008) The World's Protected Areas: status, values and prospects in the 21 st century. Prepared by the UNEP World Conservation Monitoring Centre. University of California Press, Berkeley, USA

Chen T, Bao A, Jiapaer G et al (2019) Disentangling the relative impacts of climate change and human activities on arid and semiarid grasslands in Central Asia during 1982-2015. Sci Total Environ 653:1311-1325. https://doi.org/10.1016/j.scitotenv.2018.11.058

Christenhusz MJM, Govaerts R, David JC et al (2013) Tiptoe through the tulips - cultural history, molecular phylogenetics and classification of Tulipa (Liliaceae). Bot J Linn Soc 172:280-328. https://doi. org/10.1111/boj.12061

Critical Ecosystem Partnership Fund (2016) Mountains of Central Asia. http://www.cepf.net/resources/ hotspots/Europe-and-Central-Asia/Pages/Mountains-of-Central-Asia.aspx. accessed 13 Jul 2017

de Groot JJ, Tojibaev K (2017) Tulipa zonneveldii (Liliaceae), a new species from the eastern Chatkal Mountains of Kyrgyzstan. Int Rock Gard 93:19-24

de Groot JJ, Zonneveld BJM (2020) Two new tulip species from the Altai mountains, Kazakhstan. Int Rock Gard 122:3-16

Djanibekov U, Villamor GB, Dzhakypbekova K et al (2016) Adoption of sustainable land uses in postsoviet central Asia: the case for agroforestry. Sustain 8:1-16. https://doi.org/10.3390/su8101030

Elith J, Phillips SJ, Hastie T, Dudı M (2011) A statistical explanation of MaxEnt for ecologists. Divers Distrib 17:43-57. https://doi.org/10.1111/j.1472-4642.2010.00725.x

Everett D (2013) The genus Tulipa. Tulips of the world. Kew Garden Press, London

Fick SE, Hijmans RJ (2017) Worldclim 2: new 1-km spatial resolution climate surfaces for global land areas. Int J Climatol 37:4302-4315

Flanagan SP, Forester BR, Latch EK et al (2018) Guidelines for planning genomic assessment and monitoring of locally adaptive variation to inform species conservation. Evol Appl 11:1035-1052. https://doi.org/10.1111/eva.12569

Fois M, Cuena-Lombraña A, Fenu G, Bacchetta G (2018) Using species distribution models at local scale to guide the search of poorly known species: review, methodological issues and future directions. Ecol Modell 385:124-132. https://doi.org/10.1016/j.ecolmodel.2018.07.018

GBIF.org (2020) Global Biodiversity Information Facility (GBIF) data portal. In: GBIF Home Page. https://www.gbif.org. accessed 17 Oct 2019

Graae BJ, Vandvik V, Armbruster WS et al (2018) Stay or go-how topographic complexity influences alpine plant population and community responses to climate change. Perspect Plant Ecol Evol Syst 30:41-50. https://doi.org/10.1016/j.ppees.2017.09.008

Halloy SRP, Mark AF (2003) Climate-change effects on alpine plant biodiversity: a New Zealand Perspective on quantifying the threat. Arctic Antarct Alp Res 35:248-254. https://doi.org/10.1657/ 1523-0430(2003)035[0248:CEOAPB]2.0.CO;2

Hijmans RJ (2014) raster: geographic analysis and modeling

Hof AR, Allen AM (2019) An uncertain future for the endemic Galliformes of the Caucasus. Sci Total Environ 651:725-735. https://doi.org/10.1016/j.scitotenv.2018.09.227

IUCN (2020) The IUCN Red List of Threatened Species. Version 2020-2. http://www.iucnredlist.org. accessed 25 Jun 2019

IUCN (2012) IUCN Red List Categories and Criteria. IUCN, Gland

James G, Witten D, Hastie T, Tibshirani R (2013) An introduction to statistical learning: with applications in R, 1st edn. Springer, New York

Jump AS, Peñuelas J (2005) Running to stand still: adaptation and the response of plants to rapid climate change. Ecol Lett 8:1010-1020. https://doi.org/10.1111/j.1461-0248.2005.00796.x

Kashin AS, Kritskaya TA, Schanzer IA (2016) Genetic polymorphism of Tulipa gesneriana L. evaluated on the basis of the ISSR marking data. Russ J Genet 52:1023-1033. https://doi.org/10.1134/S1022 795416100045

Keppel G, Naikatini A, Rounds IA et al (2015) Local and expert knowledge improve conservation assessment of rare and iconic Fijian tree species. Pacific Conserv Biol 21:214-219

Khassanov FO, Prastov UP (2009) Red Data Book of Uzbekistan 1. Plants. Chinor ENK Press, Tashkent

Kramer-Schadt S, Niedballa J, Pilgrim JD et al (2013) The importance of correcting for sampling bias in MaxEnt species distribution models. Divers Distrib 19:1366-1379. https://doi.org/10.1111/ddi. 12096

Krasovskaya LS, Levichev IG (1986) Flora of the Chatkal Nature Reserve. Publishing house "Fan" of Uzbek SSR, Tashkent (in Russian) 
Kumar S, Stohlgren TJ (2009) Maxent modeling for predicting suitable habitat for threatened and endangered tree Canacomyrica monticola in New Caledonia. J Ecol Nat Environ 1:94-98

Lenoir J, Gégout JC, Marquet PA et al (2008) A significant upward shift in plant species optimum elevation during the 20th century. Science 320:1768-1771. https://doi.org/10.1126/science.1156831

Liang X, Kang A, Pettorelli N (2017) Understanding habitat selection of the Vulnerable wild yak Bos mutus on the Tibetan Plateau. Oryx 51:361-369. https://doi.org/10.1017/S0030605315001155

Lioubimtseva E, Henebry GM (2009) Climate and environmental change in arid Central Asia: impacts, vulnerability, and adaptations. J Arid Environ 73:963-977. https://doi.org/10.1016/j.jaridenv.2009. 04.022

Maunder M, Cowan RS, Stranc P, Fay MF (2001) The genetic status and conservation management of two cultivated bulb species extinct in the wild: Tecophilaea cyanocrocus (Chile) and Tulipa sprengeri (Turkey). Conserv Genet 2:193-201. https://doi.org/10.1023/A:1012281827757

Menteli V, Krigas N, Avramakis M et al (2019) Endemic plants of Crete in electronic trade and wildlife tourism: current patterns and implications for conservation. J Biol Res 26:10. https://doi.org/10. 1186/s40709-019-0104-z

Merow C, Smith MJ, Silander JA Jr (2013) A practical guide to MaxEnt for modeling species' distributions: what it does, and why inputs and settings matter. Ecography (Cop) 36:1058-1069. https://doi. org/10.1111/j.1600-0587.2013.07872.x

Millaku F, Elezaj I (2015) Tulipa luanica (Liliaceae), a New Species from Southern Kosovo. Ann Bot Fenn 52:315-320. https://doi.org/10.5735/085.052.0506

Naidoo R, Gerkey D, Hole D et al (2019) Evaluating the impacts of protected areas on human well-being across the developing world. Sci Adv 5:eaav3006. https://doi.org/10.1126/sciadv.aav3006

Nic Lughadha E, Bachman SP, Leão TCC et al (2020) Extinction risk and threats to plants and fungi. Plants People Planet 2:389-408. https://doi.org/10.1002/ppp3.10146

Nowak A, Świerszcz S, Nowak S et al (2020) Red List of vascular plants of Tajikistan-the core area of the Mountains of Central Asia global biodiversity hotspot. Sci Rep 10:6235. https://doi.org/10. 1038/s41598-020-63333-9

Pacifici M, Foden WB, Visconti P et al (2015) Assessing species vulnerability to climate change. Nat Clim Chang 5:215

Parmesan C, Hanley ME (2015) Plants and climate change: complexities and surprises. Ann Bot 116:849-864. https://doi.org/10.1093/aob/mcv169

Paton A, Antonelli A, Carine $M$ et al (2020) Plant and fungal collections: current status, future perspectives. Plants People Planet 2:499-514. https://doi.org/10.1002/ppp3.10141

Pearson RG, Raxworthy CJ, Nakamura M, Peterson AT (2007) Predicting species distributions from small numbers of occurrence records: a test case using cryptic geckos in Madagascar. J Biogeogr 34:102-117. https://doi.org/10.1111/j.1365-2699.2006.01594.x

Pearson RG, Stanton JC, Shoemaker KT et al (2014) Life history and spatial traits predict extinction risk due to climate change. Nat Clim Chang 4:217

Petitpierre B, McDougall K, Seipel T et al (2016) Will climate change increase the risk of plant invasions into mountains? Ecol Appl 26:530-544. https://doi.org/10.1890/14-1871

Phillips SJ, Anderson RP, Dudík M et al (2017) Opening the black box: an open-source release of Maxent. Ecography (Cop) 40:887-893. https://doi.org/10.1111/ecog.03049

Phillips SJ, Anderson RP, Schapire RE (2006) Maximum entropy modeling of species geographic distributions. Ecol Modell 190:231-259. https://doi.org/10.1016/j.ecolmodel.2005.03.026

POWO (2019) Plants of the World Online

Pratov UP, Sharipov AH, Ashurmetov OA, Tadjibaev KS (2006) Tulips of the Western Tien Shan. Chinor ENK Press, Tashkent

QGIS Development Team (2009) QGIS geographic information system

Qin A, Liu B, Guo Q et al (2017) Maxent modeling for predicting impacts of climate change on the potential distribution of Thuja sutchuenensis. Glob Ecol Conserv 10:130-139. https://doi.org/10. 1016/j.gecco.2017.02.004

R Core Team (2020) R: A language and environment for statistical computing.

Rangwala I, Miller JR (2012) Climate change in mountains: a review of elevation-dependent warming and its possible causes. Clim Change 114:527-547. https://doi.org/10.1007/s10584-012-0419-3

Razgour O, Forester B, Taggart JB et al (2019) Considering adaptive genetic variation in climate change vulnerability assessment reduces species range loss projections. Proc Natl Acad Sci USA 116:10418-10423. https://doi.org/10.1073/pnas.1820663116

Rej JE, Joyner TA (2018) Niche modeling for the genus Pogona (Squamata: Agamidae ) in Australia : predicting past (late Quaternary ) and future (2070) areas of suitable habitat. PeerJ. https://doi.org/ 10.7717/peerj.6128 
Rodrigues ASL, Pilgrim JD, Lamoreux JF et al (2006) The value of the IUCN Red List for conservation. Trends Ecol Evol 21:71-76. https://doi.org/10.1016/j.tree.2005.10.010

Rumpf SB, Hülber K, Wessely J et al (2019) Extinction debts and colonization credits of non-forest plants in the European Alps. Nat Commun 10:4293. https://doi.org/10.1038/s41467-019-12343-X

SAEPF, IBP-NAS-KR, Aleine (2006) Kyrgyz Republic Red Data Book. FAO NFPF, Bishkek

Scherrer D, Körner C (2011) Topographically controlled thermal-habitat differentiation buffers alpine plant diversity against climate warming. J Biogeogr 38:406-416. https://doi.org/10.1111/j.13652699.2010.02407.x

de Souza AC, Prevedello JA (2020) The importance of protected areas for overexploited plants: evidence from a biodiversity hotspot. Biol Conserv 243:108482. https://doi.org/10.1016/j.biocon.2020.108482

Su Q, Qi L, Yun Y et al (2020) Visual preference of flower-visiting crab spiders (Ebrechtella tricuspidata) for host flowers. Ecol Entomol 45:626-634. https://doi.org/10.1111/een.12835

Swets JA (1988) Measuring the accuracy of diagnostic systems. Science 240:1285-1293

Syfert MM, Smith MJ, Coomes DA (2013) The effects of sampling bias and model complexity on the predictive performance of MaxEnt species distribution models. PLoS ONE. https://doi.org/10.1371/journ al.pone.0055158

Tojibaev K, Beshko N (2015) Reassessment of diversity and analysis of distribution in Tulipa (Liliaceae) in Uzbekistan. Nord J Bot 33:324-334. https://doi.org/10.1111/njb.00616

Tojibaev K, Karimov F, Oh B-U et al (2018) A checklist of the geophytes of Fergana Valley, Middle Asiaa monocotyledonous plant and biogeographical analysis. J Asia-Pacific Biodivers 11:431-441. https:// doi.org/10.1016/j.japb.2018.06.003

Tojibaev KS, de Groot JJ, Naralieva NM (2014) Tulipa intermedia sp. nov. (Liliaceae) from the Ferghana Depression, Uzbekistan. Nord J Bot 32:546-550. https://doi.org/10.1111/njb.00374

Trisurat Y, Chimchome V, Pattanavibool A et al (2013) An assessment of the distribution and conservation status of hornbill species in Thailand. Oryx 47:441-450. https://doi.org/10.1017/S0030605311001128

UNEP-WCMC and IUCN (2020) Protected Planet: The World Database on Protected Areas (WDPA)

Venter O, Fuller RA, Segan DB et al (2014) Targeting global protected area expansion for imperiled biodiversity. PLoS Biol 12:e1001891

Venter O, Magrach A, Outram N et al (2018) Bias in protected-area location and its effects on long-term aspirations of biodiversity conventions. Conserv Biol 32:127-134. https://doi.org/10.1111/cobi.12970

Vittoz P, Randin C, Dutoit A et al (2009) Low impact of climate change on subalpine grasslands in the Swiss Northern Alps. Glob Chang Biol 15:209-220. https://doi.org/10.1111/j.1365-2486.2008.01707.x

Wadgymar SM, Ogilvie JE, Inouye DW et al (2018) Phenological responses to multiple environmental drivers under climate change: insights from a long-term observational study and a manipulative field experiment. New Phytol 218:517-529. https://doi.org/10.1111/nph.15029

Warren DL, Matzke N, Cardillo M, et al (2019) ENMTools (Software Package). https://github.com/danlw arren/ENMTools

Wilford R (2013) Cultivation of Tulips. In: Linklater R (ed) The Genus Tulipa: Tulips of the World. Kew Garden Press, London

Wilson B, Mills M, Kulikov M, Clubbe C (2019) The future of walnut-fruit forests in Kyrgyzstan and the status of the iconic Endangered apple Malus niedzwetzkyana. Oryx. https://doi.org/10.1017/S0030 605318001230

Xenarios S, Gafurov A, Schmidt-Vogt D et al (2019) Climate change and adaptation of mountain societies in Central Asia: uncertainties, knowledge gaps, and data constraints. Reg Environ Chang 19:1339-1352. https://doi.org/10.1007/s10113-018-1384-9

Yesson C, Brewer PW, Sutton T et al (2007) How global is the global biodiversity information facility? PLoS ONE 2:1-10. https://doi.org/10.1371/journal.pone.0001124

Zonneveld BJM (2009) The systematic value of nuclear genome size for "all" species of Tulipa L. (Liliaceae). Plant Syst Evol 281:217-245. https://doi.org/10.1007/s00606-009-0203-7

Zonneveld BJM (2015) Tulipa jacquesii (Liliaceae), a new species from Western Kyrgyzstan. Phytotaxa 218:184-188. https://doi.org/10.11646/phytotaxa.218.2.9

Publisher's Note Springer Nature remains neutral with regard to jurisdictional claims in published maps and institutional affiliations. 


\section{Authors and Affiliations}

Brett Wilson $^{1}$ (D) Aibek Dolotbakov ${ }^{2} \cdot$ Benjamin J. Burgess $^{3}$ (D) $\cdot$ Colin Clubbe $^{4}$ (D) Georgy Lazkov² Kaiyrkul Shalpykov² (D) Myskalai Ganybaeva²

Ormon Sultangaziev $^{5}$. Samuel F. Brockington ${ }^{1}$ (D)

1 Department of Plant Sciences, University of Cambridge, Cambridge, UK

2 National Academy of Sciences of the Kyrgyz Republic, Bishkek, Kyrgyz Republic

3 Centre for Biodiversity and Environment Research, University College London, London, UK

4 Conservation Science Department, Royal Botanic Gardens, Kew, Richmond, UK

$5 \quad$ Fauna \& Flora International, Bishkek, Kyrgyz Republic 